\title{
Charges of the Funeral of Mary QueEn of Scots.
}

The Funeralles of The Accompte of John Fortescue, $\mathrm{y}^{\mathrm{e}}$ Mightie Princes (ESQUIER, keaper of the Queenes Majesty's Mary, late Quene great Warderobe, ThAт is TO SAY, Aswell of Scottes. $\quad \int$ of all such somes of moneye as he hathe receaved and had of the Queenes Majesty's threasure, out of her Highnes receipte of Thexchequier for thuse aforesaide; as also of the defrayinge, yssuinge, and expendinge the same in and aboute the empcions and provycions of blacke clothe, Parys heades, white heades, Hollande clothe, and other chardges and expences, together with cariadges and rydinge chardges of officers and others, by him defrayed in and aboute the funeralls of the late highe and mightye Princesse Marye, late Quene of Scottes, solemnyzed in the cathedrall churche of Peterboroughe, the firste daye of Auguste, in the xxixth yeare of the raigne of our moste gracious Soveraigne Ladye Elizabethe, by the grace of God, Quene of Englande, Fraunce, and Irelande, Defendor of the Faythe, \&c.

\section{That is to saye,}

The said accomptaunte is chardged withe-

Readye money receaved and had of
The Threasurer and Chamberleynes of Thexchequier by vertue of a privie seale to them dirested, bearinge date the xvjth daye of Julye, anno xxix Domine Elizabethæ 
Money chardged vppon thaccompte, viz.- - nunc Regine, as by a certificatte under thande of Roberte Petre esquier, together with the confession of this accomptaunte, may appeare, the some of . . . D.cccli.

The saide accomptaunte is further chardged with the valor or price of diverse sortes of silkes taken out of her Majesty's stoare of the greate warderobe, and spent in thaforesaide service, which are here so chardged for that allowaunce thereof is given to the same accomptaunte in diverse severall somes, hereafter particulerly sett downe in this accompte, viz. for xxviij yerdes, iij quarters, of velvett purple for the clothe of estate, at xxvj s. viij d. the yearde, $x x x v i i j l i$. vj s. viij d.; vij yeardes of purple velvett to cover the chayre of estate, at xxvj s. viij d. the yearde, ixli. vjs. viij d.; one yearde di. of satten purple at xij s., xviij s.; one yearde one quarter of purple velvett for a quyshin for the same chayre at the said rate, xxxiijs. iij d.; one yearde, iij quarters of satten purple to lyne the same, at xij s., xxjs.; and $\mathrm{xx}$ yeardes of blacke velvett for the pall remayninge over the grave, at $\mathrm{xx}$ s. the yearde, $\mathrm{xx}$ li.; amountinge in all to the some of . . . . . $1 \times x j l i . v$ s. viij d.

$\left.\begin{array}{l}\text { Some totall of all the chardge and } \\ \text { receiptes aforesaide }\end{array}\right\}$ D.ccclxxj li. v s. viij d. Against the which the saide accomptaunte is allowed for-

Boughte and provided by the saide accomptaunte for the robes and lyveryes of the mourners at thaforesaide funeralles, at severall rates and pryces as hereafter followethe; viz. at

$\mathrm{xxs}$, the yearde $\mathrm{xxxvj}$ yeardes xlv li.

$\mathrm{xx}$ s. the yearde cCxxx yeardes, iij quarters ccxxx li. $x v \mathrm{~s}$. xvj s. viij d. clxxiiij yeardes and a halfe cxlv li. viij s. iij d.

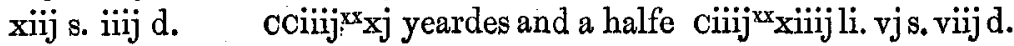


$\mathrm{X}$ s.

viij s.

vjs. viijd. clxiiij yeardes, iij quarters iij $x_{i j}$ li. vij s. vj d. ccclx yeardes and a halfe cxliij li. iiij s. cccxlj yeardes and a halfe cxiiij li. xvj s. viij d.
Blacke clothe for lyveryes for mourners, viz.

Robes and lyvereyes for $\mathbf{v}_{\mathbf{x}} \mathbf{l}$ mourners.

\section{Yeardes, M.v. ${ }^{c i i j j x}{ }^{\mathrm{xx}}$ ix di.}

Amountinge in clothe to the nomber of M.D.iiij ${ }^{\mathrm{xx}} \mathrm{xix}$ yerdes and a halfe, distributed and delivered as followethe, viz. to the Erles of Rutlande and Lincolne, at $x$ yeardes le pece, $\mathrm{xx}$ yerdes; Countesses, viz. of Bedforde, xvj yerdes, and Rutlande and Lincoln, xxiiij yerdes-xl yerdes; Bysshoppes of Lincolne and Peterboroughe, eyther of them viij yerdes, xvj yerdes; Barrons, vj, viz. $\mathrm{v}$ at viij yerdes le pece, and one, vj yerdes, xlvj yerdes; Barronesses, viij, viz. vj at $x$ yerdes the pece, and ij at vj yerdes, lxxij yerdes; Knightes, ix at vj yerdes the pece, liiij yerdes; Ladyes, iiij at vj yerdes the pece, xxiiij yerdes; Deane of Peterboroughe, viij yerdes; Master of the greate Warderobe, vj yerdes; Kinges at armes, $\ddot{i j}$, at vj yerdes the pece, xij yerdes; Scottishe gentlewoemen, vij, viz. iij at vj yerdes, and iiij at iiij yerdes, xxxiiij yerdes; Scottish gentlemen, iij, viz. $\mathrm{j}$ at vj yerdes, and $\mathrm{ij}$ at iiij yerdes the pece, xiiij yerdes; gentlemen that caryed the corpes, viij at iij yerdes di. the pece, xxviij yerdes: gentlemen vshers, ij at $v$ yerdes, $x$ yerdes; esquiers, $x v j$, at $v$ yerdes the pece, iij ${ }^{\mathrm{xx}}$ yerdes; chaplens, $\ddot{i j}$, at vj yerdes the pece, $x \mathrm{ij}$ yerdes; chauncellor to the Byshoppe of Peterboroughe, $\mathrm{v}$ yerdes; heraldes at armes, $\mathrm{v}$, at $\mathrm{v}$ yerdes the pece, xxv yerdes; sewers, $i i j$, at iiij yerdes the pece, $x i j$ yerdes; gentlewoemen attendants, xxvij, at iij yerdes di. the pece, iiij ${ }^{\mathrm{xx} x i i i j}$ yerdes di.; gentlemen attendants in clokes, xliiij, at iij yerdes di. the pece, cliiij yerdes; Mr. Roberte Petre, clarke of the receipte, $\mathrm{v}$ yerdes; 
officers of Peterboroughe churche, vj, at iij yerdes di. the pece, $\mathrm{xxj}$ yerdes; conductors in clokes, vj, viz. iij at iij yerdes, and $\mathrm{ij}$ at $\mathrm{ij}$ yerdes di. the pece, $\mathbf{x x i i j}$ yerdes; gromes of the beddes and chamber, vij, at iij yerdes di. the pece, xxiiij yerdes di.; officers of the warderobe, xiij, viz. iij at $\mathrm{v}$ yerdes, vj at iiij yerdes, and iij at iij yerdes the pece, liij yerdes; yeomen and others attendaunte in coates, ccxxxj, at one yerde and a halfe the pece, cccxlvj yerdes di.; poore woemen $\mathbf{C x x}$ at iij yerdes the pece, ccclx yerdes; in all as by one Booke of particularytyes conteyninge the severall names of the earles, countesses, barrons, barronesses, knightes, ladyes, and other persons to whom the saide clothe was distributed, signed by thande of the saide Mr. Fortescue, Master of her highnes greate warderobe aforesaid, herevppon dulye examyned, tryed, and remayninge, dothe and maye appeare, viz. in

Parys heades, whiteheades, and kerchers viz.- money . . . . . . . . ix clv li. xviij s. ij d.

Parys heades, with the furniture to them belonginge, boughte at diverse pryces, viz.: iije for the Countesses of Bedforde, Rutlande, and Lincolne, at $\dddot{i i j} l j$. xiij s. $x$.d. the pece, xiiijli. xviij.s.; $v$ at iiij li. viij s. $x d$. the pece, xxij li. iiij s. ij d.; vi, with barbe and lyninge to eche of them, at lxx s. the pece, xxj li.; vj Parys heades, vj barbes, and $v j$ lardge bongraces, at lxij s. the pece, xviij li. xij s.-in all . . . . l lxxv li. xvij s. viij d.

Whiteheades for gentlewoemen attendaunte uppon the mourners-x, at xxiij s. the pece : . . • xjli.xs.

A lardge attyre of lawne, with a barbe, for a Scottish gentlewoeman . $\cdot$ • $• \quad \cdot \quad \cdot \quad \cdot$ xxiij s. Heade attyres for gentlemen attendaunte-v, at xiij s. vi d.

Kerchers, likewise boughte for gentlewoemen, of diverse lxxij s. vi d. sortes, viz.; v, at $\operatorname{xxvs}$. the pece, vjli. v s.; vi, at 
xvjs. the pece, iiijli. xvj s.; and one, xiiijs. vj d.-in

all the some of . . . . . $\quad x j l i . x v d . ~ v j d$.

Hollande for kerchers for Cxx poore woemen, Cxx ells, at ij s. the ell

A clothe of estate, chayre, and quyshin of purple velvett, viz.-
Money by him Purple velvett for the clothe of estate of yssued, payde, and defrayed, viz.: for-

Buckram to lyne the same, xviij yerdes, at xiiij d. le yerde

Rounde Lyor, iiij li., at iijs. iiijd. the pounde . xiij s. iijj d. Makinge of the same . . . . . . lxvjs. viij d. Purple sylke frendge, $\mathrm{jlb}$. x oz., at iij s. the oz. . . lxxviij s. Silke, ij oz., at ij s. vi d. the oz. the stoare of the greate warderobe, xxviij yerdes ijje quarters, at xxvjs. viij d. the yearde . xxxviijli. vj s. viij d. xxjs.
iijj d.
viij d.
xviij s.
vs.

(Total) xlvii li. x s. viij d.

Tymberworke of a chayre for the same state . . xiij s. iiij d. Purple velvett to cover the chayre of the saide stoare, vij yerdes, at xxvis. viij d. the yerde . . ix li. vj s. viij d. Purple satten to lyne the backe of the same of thaforesaide store, $j$ yerd di., at xij s. . . . . . . . xviij s. Purple silke frendge, xij oz. qu., at iij s. the ounce . $x x x v j s . i x d$. Purple silke; joz. di. qu. . . . . ij s. ix d. ob. qu. Narrowe silke rybben, ij oz., at iiij s. the ounce . . viijs. Girthwebbe, sackclothe, buckrom, and blacke nayles . iij s. vj d. Fustyon, iij yerdes, at xviij d. the yearde . . iiij s. vid. Downe, vi lb., at xviij d. the pounde . . . . ix s. Blacke vernished nayles, m. . . . . vi v. viij d. Greate chayre nayles, j doz. . . . . . . . . . jjs. vj d. A scutchin and pomells 
Canvas for the backe

A staye of yron for the backe

Workemanshippe, with $\mathrm{x}$. for a case of cotton xviij d.

- ij s. vj d.

(Total) xvj li. vij s. viij d. ob. qu.

Purple velvett for a quyshin for $\mathrm{y}^{\mathrm{e}}$ same chayre, $\mathrm{j}$ yerde qu., at $x \times v j$ s. viij d. the yearde, taken out of the stoare of the warderobe

- xxxiij s. iij d.

Purple satten to lyne the same of the saide stoare, $\mathrm{j}$ yerde iije quarters, at xij s. the yearde . . . . . xxi s. Purple silke, iij oz. di. qu., at iij s. the ounce . . . ix s. iij d. ob. Lardge buttons, caules, and tassells of purple silke, iij oz.,

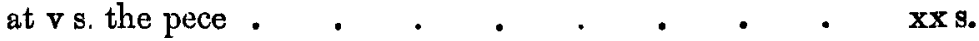

Fustyon for the pillowe, iije yerdes, at xviij d. le yearde iij s. vid. Fine downe, viij lb., at ij s. the pounde . . . . . xvj s.

(Total) ciij s. ij d. ob.

(Total) lxix li. ij s. vij d. qu.

A pall of blacke velvett remayninge over the grave at Peterboroughe, viz.,
Blacke velvett for the same pall, beinge taken out of the said stoare of her Majesty's warderobe, xx yeardes, at $\mathrm{xx}$ s. the yearde, the some of . . . . . $\mathrm{xxli}$. Black buckrom for lyninge the same, xij yerdes, at xiij $d$. the yearde, the some of . . . . . . . xiij s. (Total) $\mathrm{xx}$ li, xiiij s.

Hanginges and Blacke clothe, aswell to hange in the chamber of presence carpettes of blacke clothe and broade bayes, viz.and aboute the pulpitt, as also for two carpettes in the chamber of presence, cciijjxx viij yeardes, at vj s. viij d. the yearde

Broade bayes to hange in the withdrawinge chamber, CAMD. sOC.
F 
the hall, and diverse other places as the mourners passed by, and for a sparver in the said chamber, vij ${ }^{1 i j j}{ }^{x x} \times x_{i j}$ yerdes qu., at iij s. iiij d. le yearde . . cxxxij li. vij s. vjd. And to William Albanye, for the hyer of vij ${ }^{0}{ }^{i i j j x}$ xix yerdes

iije qus. of like bayes, which was hanged in the churche and the portes of the same, at iij d. the yearde, the some of

$$
\text { (Total) ccxlj li. xiiij s. jd. }
$$

Offeringes, viz.-

Duetyes of the churehe of Peterboroughe, viz.-
Doole moneye, viz.-

Rydinge chardges of officers to Peterboroughe, with a rewarde, viz.-
Also allowed to the saide accomptaunte for so much money by him saide to be payde to the mourners for there offeringes in the churche, the some of . . . Also allowed to the Deane of Peterboroughe for sondrye duetyes of the churche, viz.: for the grave, $x$ li.; rynginge, lxvj s. viij $d$.; rushes and strawinges, ls.; demolicions and spoyles of thinges in the churche, lxvj s. viijd.; careinge the corpes to the grave in the nighte, $\mathrm{xxs.}$; for thuse of the vestrie for kepinge $\mathrm{y}^{\mathrm{e}}$ clothes, $x$ s.; perfumes, ij s. vj d.; and to $y^{e}$ saide Deane, in consideracon of the blacke bayes $y^{t}$ hanged in the churche, $x x$ li.-- in all . . . . . $x l$ li. $x v$ s. $x d$. Payde by thandes of Mr. John Fortescue in almes delivered to $\operatorname{cxx}$ poore woemen in money at the saide funeralles, the some of John Fortescue, deputie to the master of the warderobe, for the chardges of him selfe, his man, and horses, by the space of $\mathrm{xv}$ dayes, and for his service and attendannce, the some of

Roberte Tyos, vnder clarke of the same warderobe, for his chardges, service, and attendance by the lyke tyme, and for ynke and paper : . . . . . John Tute, portitor, and Roberte Welton, measurer of the clothes, for them selves and there horses, there services xij li. $\mathrm{xli}$. vij li. 
and attendaunce for lyke tyme, at iiij li. to eyther of them

Hughe Rogers, for the chardges of him selfe, his wyfe, and horses, to see to the orderinge of the Parys heades. Anthonye Walker, clarke of the greate warderobe, for his diligence, travell, and attendaunce, in tryinge, castinge, exameninge, and makinge of this accompte. vj li. xiij s. iiij d.

(Total) xxxiij li. xiij s. iiij d.

Chardges of John Tute, portitor of the great warderobe, for the cariadges, viz., chardges of three cartes, to Peterboroughe, and twoe

Wages of taylors, with other neccessaries, viz., ofbacke againe to the greate warderobe, in cariadge and recarriadge of the blacke clothes, Parys heades, bayes, and other the provicions aforesaide, for the same fune-

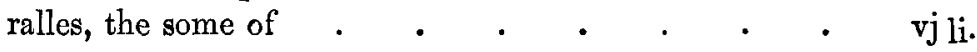

WilliamWallys, William Powell, Evan Price, James Rutter, Rowlande Rugger, John Allen, Edward Graveleye, and Edmonde Rowse, for there wages, travell, and attend. annces at London and at Peterboroughe, in sowinge and hanginge of all the bayes, and in deliverye of all the blackes, everye of them by the space of $x v$ dayes, at $\mathrm{xxd}$. the daye, amounting in all to the some of . $\quad x$ li.

To certen taylors hyred at Peterboroughe, xiij s.; makinge of the gownes for the poore, $\mathrm{vj}$ li.; and for diverse other necessaries, viz.: greate hookes, boordes, and quarters to hange the clothe of estate, and for watchinge, v s. iiij d.; hookes, MM., at xiijs. iiijd. le mille, xxvj s. viijd.; twoe hamers, vs.; and for curten ringes and tape for a sparver of bayes hanged in the withdrawinge chamber, ij s. iiij d.-xxxix s. iiij d.; in all the some of xviij li. xij s. iiij d. 
And allowed to John Fortescue, master of the greate warderobe, for the chardges of him selfe, his servanntes, and horses, in his yorneye to Peterboroughe and duringe his aboade there

In all the chardges of the saide funeralles solemnysed in the Cathedrall Churche of Peterboroughe aforesaide, as by one Booke of particularytyes thereof subscribed with thande of John Fortescue, esquier, master of the greate warderobe, herevppon beinge duelye caste, tryed, and examyned, may appeare, the some of . M.D.xxxvjli. ixs. qu.

(Some totall of all the paymente and allowaunces aforesaide, with lxxj li. v s. viij d. for the valor and price of silkes expended out of the stoare of the great warderobe) - M.D.xxxvj li. ix s. qu.

Over and beside the some of - payd to the harraldes by agrement with my Lord Threasurer, and the some of —_ for the dyett in this accompte not accompted for.

And so he restethe in supplusage vppon the determynacion of this accompte the some of - D.clxv li. iij s. iij d. qu. Whereunto is to be added for the travell, paynes, and expences of John Conyers, auditor, and his clarkes, in tryinge, castinge, and exameninge the particuler Bookes of the said accomptaunte, and reducinge the same into an accompte, and for engrossinge the said accompte in parchemente, the some of $\mathrm{xl} \mathrm{s.;} \mathrm{and} \mathrm{then} \mathrm{he} \mathrm{remaynethe}$ in supplusage the some of . - . D.clxvij li. iij s. iij d. qu. xiijo Februarii, 1587.

W. Burghlex, Wa. Mildmaye.

Examined per Jo. Conyers, Auditor. iiij ${ }^{x x}$ xiiij li. x s. ix d. sol. in parte supplusage. 


\section{Charges of the Hearse.}

Chardges of the hearse,
The Accompte of WinLram Detricke,
and other of
herauldrie, at the fune-
rall of the Scottishe.
Soveraigne Ladye Elizabeth the Quene's
Maiestie that nowe ys, for the some of
fower hundreth and sixe poundes by him
receaved and hadd out of her highnes Receipte of the Exchequier by vertue of a privie seale dated $x^{\text {mo }}{ }^{\mathrm{July}}, 1587$, for provicions to be made for the hearse and other causes of Herauldrie for the funeralles of the Scottishe Quene, primo die Augusti, 1587, in the xxxth yere of the Reigne of our gratious Soueraigne Ladye Eliza. beth, by the grace of God Queene of Englande, Frannce, and Irelande, Defendor of the Faythe, \&c., WHICH said some of fower [hundred] and sixe poundes dependeth vpon him in the accompte of Anthonie Pawlett esquier, heyre and executor to Sir Amyas Pawlett knighte, late gouernor of the Quene of Scottes, for her dyet at Tutburie, Chartley, and Fotheringay, made for twoe whole yeares fyue monethes and xviijth dayes, endinge the iiijth daye of Auguste, anno regni Regine predicte $\mathrm{xxxix}^{0}$, for whiche some the saide William Dethicke Garter Accomptaunte, dothe yelde and make this his presente accompte, as hereafter followeth, which accompte was taken and declared before the righte honorable (sic)

\section{That YS TO SAYE,}

Readie money by him received and hadd; viz. of-
The Threasurer and 7 In the Terme of Easter, anno $x x^{2} x^{\text {no }}$ Chamberlaines of $\}$ Regine predicte, by the handes of Theschequier; viz.- $\}$ Sir Henrie Killigrewe, knighte, one of the Tellors of the Receipte of the Eschequier, by vertue of a privie seale dated $\mathrm{xj}^{\mathrm{mo}}$ die Julii, 1578 , for provicions to be made for the hearse and other causes of Herauldrie againste the Funeralles of the said Scottishe 
Queene, as in the chardge of the accompte of the saide Anthonie Paulett, esquier, in the title of money receaved of the Threasurer and Chamberlaines of the Eschequier appeareth, whiche afterwardes in the foote of the same accompte was sett vpon the saide William Dethicke, Garter, nowe accomptaunte, to be by him accompted for, amountinge to the some of . . ccccrjli.

Agaynst the which

The saide accomptaunte is allowed for-

Firste, the accomptaunte ys allowed aswell for sondrie kindes of emptions and provicions made and prouided for the saide hearse, with velvetts, silkes, and other furnitures, and garnishinges of golde and silver, the Banner of Honor of the Armes of the said Scottishe Quene, escutchions, and other neccessaries; as also for the fees, dyettes, attendaunce, ryding chardges, and other expences of the saide William Dethicke, alias Garter principall Kinge of Armes, Roberte Coke, alias Clarentiux, and William Flower, alias Norrey, twoe other Kinges of Armes, with other chardges of herauldes, pursuvauntes and others, as hereafter particulerly ensueth; viz. for-

A frame of timber, and makinge a hearse with doble railes, which was sett vp and erected in the quier of the Cathedrall Churche at Peterburgh, before the firste daye of Auguste, 1587, on which daye the funeralles were solempnized, the some of . . . . . . xvjli.

A chariot or choache to convey the corpes, wrapped and soldred in leade, with representacion of $\mathrm{y}^{\mathrm{e}}$ saide Scottishe Quene, from Fotheringaie to Peterborough, and for paintinge and garnishinge the same chariott, xiij li. vj s. viij d.; and for hier and chardges of iijor choch horses from London to drawe $\mathrm{y}^{\mathrm{e}}$ same chariott, beinge trapped 
with velved, and garnished with eschutchions and chafferons, cs. In all . . . . . xviij li. vj s. viijd.

A pyllowe of purple velvett, frindged and tasselles of golde, for the state of representacion . . . lxvj s. viij d.

Emptions and provisions of sondrie kindes imployed aboute the hearse; viz. for-
Velvettes imployed for the furnishinge of the saide hearse and funeralles; viz. $\mathbf{x}$ yardes of blacke velvett to cover $\mathrm{y}^{\mathrm{e}}$ saide chariott, frindged with blacke silke and golde, and garnished with eschutchions; $x \times x$ yardes of velvett for a pall for the corpes, and ix yardes of velvett for a cannopie to be caried over the corpes, which was frindged with silke and golde, with iiijor blacke staves with knoppes of golde to beare the same cannopie; also velvettes aboute the same hearse for vallaunces and rochementes of xviij yardes compasse, conteyninge doble $\mathrm{ij}^{\circ}$ breadthes of veluette-xxxvj yardes; velvett for the viij pillers of the hearse, for everie piller ij yardes di., conteyninge $\mathbf{x x}$ yardes; and for $\mathrm{ij}$ carpettes and $\mathrm{ij}^{\mathrm{e}}$ pillowers of blacke velvett within the hearse, and at the offeringe for the cheife morner, conteyninge xiiij yardes. In all cxix yardes, at xviij s. the yarde, amountinge to

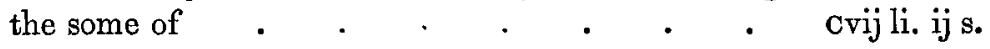

Lardge frendge of golde, of one quarter depe, conteyninge - yardes fastned to $y^{e}$ vallaunce of the hearse, and for xviij yardes of blacke silke frindge fastned to the ciell or majestie of the hearse, and frendge for the chariott or cannopie . . . . . . . xiij li. vj s. viij d.

Blacke taffata: ij ells for $y^{e}$ ciell or majesty within the herse, buckrome to line yt, and for makinge iiijli. xvj s. iiij d.

Blacke clothe: lxx yardes to couer the compasse of the 
saide doble railes and hearse, for consideracion at viij s. the yarde; and for lviij yardes of bayes for th'inner parte of $\mathrm{y}^{\mathrm{e}}$ railes and for stole clothes. In all the some of . . . . . . . . . . . . . . . .

(Total) ciiij ${ }^{x x} x v j$ li. xiiij s. iij d.

Money by him yssued, payde, and defrayed; viz.-
Empcions and provisions of banners. eschutchions, and other garnishinges for royall solemnizinge of the sayde funeralles; viz. of-
\}$^{T}$ The greate Banner of Honor of the armes of the saide Scottishe Quene, wroughte on taffata with fine golde in oyle, frendged with silke, and for a longe standarde of taffata wrought with the supporters, creast, and badges, with oile in fine golde; for xij bannerrolles of her royall dissentes and armes of her antecessors, likewise on taffata, wrought wyth golde in oyle, and frendged with silke; for a coate of her armes vpon damaske, wrought with fyne golde in oile, and lined with buckram; for a lardge helmett of steele, with bales gilte in fine golde; the creaste or cognizance carved, and gilte with fyne golde; the targett of her armes, carved in woodd, gilte with fine golde; the sworde and the pommell gylded; the sheathe of clothe of golde, with a girdle, buckler, pendaunte; and the mantles of clothe of golde, lined with clothe of silver, powdered with ermynes, the knoppes burnished golde, with tasselles of silke and golde, and a crowne with balles, doble gilte, sett with a crowne. Amounting in all to . liij li. vj s. viij d.

xviij compartement eschutchions in paste paper or boordes, xij scroules of her worde written and gilte, xviij water tables with armes and supportors, and xij shafferons of 
armes in paste paper, and for creaste and cognizaunces of her badges and supportors . . . . . . ix li.

xiij dozen of pencelles of severall coates of armes and badges or creastes wroughte vpon taffata and sarcenett in golde, for the garnishinge of the hearse or chariott; also vj eschutchions on taffata in fine golde, for the corpes sett vpon the pall . . . . . . viijli.

iiij dozen of eschutchions of her armes, single, and with her late husbande impaled, made vpon lardge brckram; $\mathbf{x}$ dozen of eschutchions vpon paper in metall; and xij dozen on paper in coullors, for the garnishinge of the churche, and for one longe attachemente of armes, with helme, creaste, and supportors . . $\quad x x x v j$ li. xiij s. iiij d.

$\mathrm{xv}$ braces of irons to be fastned in $\mathrm{y}^{\mathrm{e}}$ churche, to beare $\mathrm{y}^{\mathrm{e}}$ banners, bannerrolles, helmett, creaste, and such like; also for xiij longe blacke staues for $y^{e}$ said banners; and xxiiij shorte blacke staues for the conductors, eighte white staves for the offycers royall, nailles, pynnes, \&c., and for twoe longe trunckes, and carriadge of the saide banners and eschutchions, with the velvettes and other thinges, to Peterburghe . . . . . . viij li:

Fees, dyetts, riding chardges, and other allowaunces of the Kinges of Armes, Herauldes, and pursuvauntes ; viz. for-
William Dethicke, alias Garter, principall Kinge of Armes, aswell for his transportacion and riding chardges from London to Peterborough, and from thence to Fotheringay, to prepare for the conducte and safe carriage of the corpes of the Scottishe Quene, as also for his fees, dyetts, and attendaunce duringe the saide furieralles, the some of
G xlv li. 
Roberte Cooke, alias Clarentiux, Kinge of Armes, for his like riding chardges; fees, dyettes, and allowaunces, dueringe all the saide tyme of the funeralls . . . $\mathbf{x x v}$ li. William Flower, alias Norrey, Kinge of Armes, for his fees allowed to $\mathrm{y}^{\mathrm{e}}$ heraulde his deputie, as in like cases apperteyned . . . . . . . xviijli. vjs. viijd.

Twoe herauldes for their fees, riding charges, transportacion, with dietts and other allowaunces dueringe the foresaide tyme . . . . . . xviij li. vj s. viij d.

Twoe pursuvauntes of armes for their fees, riding chardges, transportacion, dyetts, \&c., for the same tyme. . . . . . . . . xiij li. vj s. viijd.

Amountinge in all the chardges aforesaide, as by one rolle thereof in parchement subscribed with thande of this accomptaunte herevpon examined and remayninge, maye appere, to $\mathrm{y}^{\mathrm{e}}$ some of . . . . . . cxxli.

And so the saide accomptant vpon $y^{e}$ determinacion of this his accompte is in supplusage the some of $x v$ li. xiiij s. iij d.

Which some, for that the same chardges was undertaken by agremente with the righte Honorable Lorde Burghley, late Lorde High Threasurer of Englande, and Sir John Fortescue, knighte, Chancellor of the Eschequier, for the saide some of ccccvj li., ys here for that cause deducted from this accomptaunte.

AND so HERE EVEN.

$\mathrm{xvj}^{\text {to }}$ die Februarii.

J. Fortescue.

Examined per Fra...... Roberte Clarke. $\mathrm{W} \ldots \ldots . . .$. 